\title{
FRANK W. HANKINS (1897-1983): AN APPRECIATION
}

\author{
RALPH H. WETMORE
}

During the academic year of 1958-59, Mr. Frank W. Hankins of Alpine, Texas made his first appearance at the laboratory of Professor Elso S. Barghoorn at Harvard University. He had heard of the Harvard Wood Collection and was seriously interested. Professor Barghoorn was obviously intrigued by the discussion and increasingly so for Mr. Hankins wanted to return and to maintain definite relations with him and with the Wood Collection. Professor Barghoorn encouraged this relationship, since Mr. Hankins had retired from his consulting business in Texas and was investigating possible fields in which he might direct his efforts as a major concern. Having already visited other wood laboratories in the United States, he established a technical laboratory at Sul Ross State University in Alpine, Texas, and recruited staff members to permit progress in acquiring knowledge in the study of wood.

For twenty-five years (1958-1983) he maintained his association with Professor Barghoorn and the Harvard Wood Collection, returning to Harvard each year for varying periods of time, for discussions and reporting progress. For two years he was appointed as a member of the Visiting Committee for Biology of the Harvard Board of Overseers and attended the joint meetings of this committee with the Harvard Faculty of Biology. During this period, $\mathrm{Mr}$. Hankins maintained a very concerned, interested and informed relationship with the Harvard Wood Collection and its staff. He established a collection of wood samples from trees and shrubs of Gymnosperms and Angiosperms in his own laboratory and built up a small staff at the local college, Sul Ross State University, in Alpine, Texas. He made microscopic wood slides or made connections with competent staff members at other universities where excellent microscopic slides could be prepared and initially evaluated. These slides and those made 
anew from documented wood blocks gathered from various xylaria, were then examined by Mr. Hankins himself, and on his regular visits to Professor Barghoorn these slides were added to the Harvard Wood Collection. Mr. Hankins and his staff added greatly to the Harvard Wood Collection through his contributions of microscopic slides of woods made from blocks from Harvard's collection, from his personal collection, and those made for him by his collaborators at other institutions.

Mr. Hankins' recent death on October 9, 1983, has resulted in the addition of the entire Frank W. Hankins collection-of correspondence files, data files, wood anatomical identification "keycards" and microfiche thereof, wood blocks, and prepared microscopic slides - to the Harvard Wood Collection.

Those responsible for the Harvard Wood Collection, and the staff and students of Harvard's Department of Organismic and Evolutionary Biology always will be grateful for the significant contribution of Frank Hankins and his staff in Alpine, Texas, and to Mr. Hankins' colleague, Professor Lyman H. Daugherty of San José, California, who completed a large part of the preparation of these microscopic slides donated to the Wood Collection by Mr. Hankins.

For seven years (1976-1983), Mr. Hankins was a member of the Botanical Museum staff as Associate in Paleobotany.

Unfortunately, Professor Barghoorn's unexpected and sudden death on January 27, 1984, leaves the Harvard Wood Collection without an official Supervisor at present. This very warm and appreciative note was written on Professor Barghoorn's behalf. 


\section{$2 \mathrm{BHL}$ Biodiversity Heritage Library}

Wetmore, Ralph H. 1985. "Frank W. Hankins (1897-1983): An Appreciation." Botanical Museum leaflets, Harvard University 30(2), 89-90.

https://doi.org/10.5962/p.168672.

View This Item Online: https://www.biodiversitylibrary.org/item/31877

DOI: https://doi.org/10.5962/p.168672

Permalink: https://www.biodiversitylibrary.org/partpdf/168672

\section{Holding Institution}

Missouri Botanical Garden, Peter H. Raven Library

\section{Sponsored by}

Missouri Botanical Garden

\section{Copyright \& Reuse}

Copyright Status: Public domain. The BHL considers that this work is no longer under copyright protection.

This document was created from content at the Biodiversity Heritage Library, the world's largest open access digital library for biodiversity literature and archives. Visit BHL at https://www.biodiversitylibrary.org. 